\title{
The Effectiveness of Hypnotherapy in Reducing Pain in Patients with Cervical Cancer
}

\author{
Hanung Prasetya' ${ }^{1)}$, Heni Nur Kusumawati'), Wardiyatmi²) \\ ${ }^{1)}$ Study Program in Acupuncture, Health Polytechnics, Ministry of Health Surakarta \\ ${ }^{2)}$ Dr. Moewardi Hospital, Surakarta
}

\section{ABSTRACT}

Background: Complaints of pain in cervical cancer patients make the patient suffer more. Pain is a subjective matter so that hypnotherapy can reduce the pain suffered by patients. The use of hypnotherapy in cancer patients focuses on the emotional aspects and dynamics that occur in the client's subconscious mind. Hypnotherapy can change sensations, perceptions, thoughts, feelings or behavior after being suggested. Positive suggestions given are able to influence the perception of someone who is in a hypnotic state so that they behave or perceive according to the suggestions given. The purpose of this study was to analyze the effect of hypnotherapy as a complementary therapy in reducing pain in cervical cancer patients.

Subjects and Method: The experimental study used a random control trial which was conducted at the Dr. Moewardi Hospital from January to September 2019. A sample of 90 patients was selected by purposive sampling. 45 subjects from the treatment group received the hypnotherapy intervention and 45 subjects from the control group received standard care. The dependent variable is the level of pain. The independent variable is hypnotherapy. The level of pain is measured by a numerical pain scale of $o$ to 10. Hypnotherapy is performed using hypnosis recording/ audio. Data analysis was performed using an independent $t$ test.

Results: The mean pain level after hypnotherapy (Mean=0.8; $\mathrm{SD}=1.96)$ was lower than the control group $(\mathrm{Mean}=3.2 ; \mathrm{SD}=1.7)$, effect size $=-1.31$, and it was statistically significant ( $p$ $<0.001$ ).

Conclusion: Hypnotherapy complementary therapy can help reduce pain levels in cervical cancer patients.

Keywords: hypnotherapy, pain, cervical cancer

\section{Correspondence:}

Hanung Prasetya. Study Program in Acupuncture, Health Polytechnics, Ministry of Health. Jl. Letjend Sutoyo, Mojosongo, Surakarta 57127, Central Java. Email: Hanungprasetya71@yahoo.com. Mobile: +628122638908.

Cite this as:

Prasetya H, Kusumawati HN, Wardiyatmi (2021). The Effectiveness of Hypnotherapy in Reducing Pain in Patients with Cervical Cancer. Indones J Med. 06(02): 152-158. https://doi.org/10.26911/theijmed.2021.06.02.04.

\section{BACKGROUND}

According to the World Health Organization (WHO), Indonesia is a country with the largest number of cervical cancer sufferers in the world (Ministry of Health, 2015). The prevalence of cervical cancer was $0.8 \%$ o and the prevalence of breast cancer was 0.5 $\%$. The discovery of various new treatment methods has increased the average age of cancer patients longer, and this means that they will experience longer cancer pain, either due to the disease itself or from treatment (Wargo and Burton, 2005). According to Lukman and Harjanto (2007) the management of cancer pain is still below standard, it is said that $50 \%$ of patients with cancer and $90 \%$ of patients with advanced stages suffer from pain. $70 \%$ of 
cancer pain results from involvement of the tumor in the soft, visceral, nerve, or bone tissue. Cancer pain can also come from changes in the body's structure due to the tumor, while $25 \%$ of cancer pain comes from the impact of giving cancer therapy such as radiotherapy, chemotherapy, immunotherapy and/ or surgery (Wargo and Burton, 2005). The suffering of cancer patients can be doubled if you do not get adequate pain management therapy. As a spiritual biopsychosocial being, the patient also suffers from common symptoms of cancer such as fatigue, weakness, nausea, constipation and decreased cognitive function.

The use of complementary therapies is increasingly being used, including hypnotherapy. As a mind-body therapy, hypnotherapy is able to bring patients into a very deep hypnotic state, experience mental imagery and can receive therapeutic suggestions. Various ways can be done to manage pain including hypnotherapy.

Hypnotherapy is a hypnosis application in curing mental disorders and relieving physical disorders (Arter, 2014). Hypnosis can change sensations, perceptions, thoughts, feelings or behavior after suggestion. A brain that has been influenced by suggestion will instruct the central nervous system to directly stimulate the Reticular Activating System to reduce its performance so that it has an impact on the release of serotonin from specific cells in the pons and brainstem, namely Bulbar Synchronizing Regional (BSR) (Tarwoto and Wartonah, 2010). When the client's condition is relaxed, the next RAS activation decreases and the BSR will take over, causing the client to fall asleep (Potter \& Perry, 2005). Positive suggestions given are able to influence the perception of someone who is in a hypnotic state so that they behave or perceive according to the suggestions given.
The use of hypnotherapy in cancer patients focuses on the emotional aspects and dynamics that occur in the client's subconscious mind. Pain is a subjective matter so that hypnotherapy can reduce the pain suffered by patients. One of the causes of cancer is the decreased performance of the immune system due to chronic stress experienced by a person, this is where hypnotherapy can play a role in helping cancer sufferers. According to Prasetya (2018), in Indonesia, there are still many people who consider hypnosis a mystical thing and are often associated with crime. In fact, hypnosis is scientific knowledge and has been recognized by WHO as a safe method of therapy. In developed countries such as America and England, many doctors, psychiatrists, psychologists, and hypnotherapists have used hypnosis to treat physical and psychological problems. Since 1955 the British Medical Association, 1958 American Medical Association and 1960 American Psychological Association officially legalized hypnosis as a legal therapeutic tool even now hypnosis is widely taught in many medical schools, especially in America.

\section{SUBJECTS AND METHOD}

\section{Study design}

This was an experimental study which was conducted using the Random Control Trial. The research was conducted at the Dr Moewardi Hospital Surakarta in 2019.

\section{Population and samples}

The population of this study includes all cervical cancer patients at Dr Moewardi Hospital Surakarta who experienced pain throughout January to September 2019. The sample was 90 patients who were randomly divided into 2 groups into control and treatment groups. Inclusion criteria Cervical cancer patients who are treated at the Dr Moewardi Hospital Surakarta, the patient experiences complaints of pain 
related to his illness, can communicate in Indonesian, has good hearing, is willing to do hypnotherapy intervention every day at least once for seven consecutive days. Pain exclusion criteria are not related to cervical cancer, have sensory impairments, are not willing to participate in hypnotherapy intervention every day at least once for seven consecutive days.

\section{Study variables}

The dependent variable was pain. The independent variable was hypnotherapy

\section{Operational definition of variables}

Hypnotherapy was the provision of therapeutic intervention using hypnotherapy to cervical cancer patients who experience pain, at least once per day for 7 consecutive days. Hypnotherapy is carried out by giving suggestions in the form of an invitation to accept and live the problem while remaining grateful even though it is difficult. Hypnotherapy is administered using audio recordings recorded on the patient's cellphone. The level of pain is a feeling or uncomfortable condition due to pain due to cervical cancer or cervical cancer treatment activities. The coding in this study was "yes" for the treatment group and "no" for the control group. The data used in the group were nominal dichotomous including categorical data.

\section{Data Analysis}

The difference in pain levels in cervical cancer patients was measured before and after treatment and then analyzed by test in the SPSS program.

\section{Research Ethic}

Subjects who fit the inclusion criteria were given an explanation of the objectives, benefits, assurance of confidentiality and what to do in providing answers to the questions on the questionnaire. All subjects in this study had signed a letter of approval to become respondents. This research has passed the research ethics committee of Poltekkes Kemenkes Surakarta with number: LB.02.02 / 1.3 / 1683/2019

\section{RESULTS}

\section{Univariate analysis}

The description of the univariate analysis describes the general characteristics of the sample data for each variable including data on age, education and occupation. Univariate analysis can be seen in tables 1 and 2.

Table 1. Sample characteristics of continous data

\begin{tabular}{cccccc}
\hline Group & n & Mean & SD & Min. & Max. \\
\hline Age (Years) & 90 & 44.21 & 11.96 & 20 & 68 \\
\hline
\end{tabular}

\section{Bivariate analysis}

The bivariate analysis in this study used an independent $t$ test to test the mean difference between the independent and dependent variables. The results of the different pain levels in the hypnotherapy intervention group and the standard care group are presented in table 2 .

Table 3 shows that there was no difference in mean pain between the hypno- therapy group before the intervention, and it was not statistically significant $(p=$ o.885).

These results indicate that randomization carried out in allocating into the hypnotherapy group and not hypnotherapy was successful in making the two groups comparable at the initial pain level before the intervention. 
Prasetya et al./ The Effectiveness of Hypnotherapy in Reducing Pain

Table 2. Sample characteristics of categorical data

\begin{tabular}{lcc}
\hline \multicolumn{1}{c}{ Variables } & n & \% \\
\hline Education & & \\
ES & 14 & 15.5 \\
JHS & 16 & 17.7 \\
SHS & 19 & 21.1 \\
College & 41 & 45.5 \\
Employment & & \\
House Wife & 38 & 42.2 \\
Laborer & 10 & 11 \\
Entrepreneur & 18 & 2 \\
Civil Servant & 8 & 0.88 \\
Student & 9 & 10 \\
Farmer & 7 & 0.77 \\
\hline
\end{tabular}

Table 3. Results of mean t-test differences in pain levels in the hypnotherapy and non-hypnotherapy groups before the intervention

\begin{tabular}{lcccc}
\hline \multicolumn{1}{c}{ Group } & n & Mean & SD & p \\
\hline Hypnotherapy & 45 & 3.91 & 1.98 & 0.885 \\
Non Hypnotherapy & 45 & 3.66 & 1.96 & \\
\hline
\end{tabular}

Table 4 shows that the mean pain in the hypnotherapy group (Mean= $0.8 ; \mathrm{SD}=$ 1.96) was lower than that in the nonhypnotherapy group (Mean= 3.2; $\mathrm{SD}=1.7$ ). The difference was statistically significant ( $\mathrm{p}<0.001)$.

Table 4. Average results of differences in pain levels in the hypnotherapy and non-hypnotherapy groups after the intervention

\begin{tabular}{lcccc}
\hline \multicolumn{1}{c}{ Group } & n & Mean & SD & p \\
\hline Hypnotherapy & 45 & 0.8 & 1.96 & $<0.001$ \\
Non Hypnotherapy & 45 & 3.2 & 1.7 & \\
\hline
\end{tabular}

\section{Size Effect}

The effect of the use of hypnotherapy on reducing the pain level of cancer patients is known based on the calculation is equal to 1.31. Based on the standard Cohen size effect having a value of 0.8 - 2.0 has a strong effect. Thus, the use of hypnotherapy has a strong influence in reducing pain in cervical cancer patients.

\section{DISCUSSION}

The results of the study used an independent $t$ test to determine the effect of hypnotherapy in the control group and the treatment group. The data in Table 4 shows
These findings indicate that hypnotherapy is effective in reducing pain in cervical cancer patients. These results come from an RCT. that patients who received hypnotherapy had lower mean pain rates than the control group who only received standard care.

This study strengthens the opinion that a thought program that has been implanted through affirmations and suggestions in a hypnotic state, can be a trigger for permanent change (Beneditis, 2015). The hypnotic state begins with focusing one's attention, creating a relaxation response through induction and deepening techniques (Daitch, 2018). The placebo effect occurs when a person responds to medication or other action because of the hope that the treatment will actually work. 
Accepting treatment or action alone is a positive effect.

Patients' positive expectations about treatment can increase the effectiveness of giving hypnotherapy interventions. Often the more clues a patient receives about the effectiveness of an intervention, the more effective the intervention will be. Individuals who were told that a medication was thought to provide pain relief was almost certainly more likely to experience pain relief than patients who were told that their medication had no effect. Positive patienthealth worker relationships can also be a very important role in enhancing the placebo effect (Smeltzer \& Bare, 2002).

Hypnosis therapy is effective at modulating pain perception by affecting a person's cognitive processes compared to individuals who do not receive hypnosis therapy. The subconscious mind is a place where humans store all beliefs, values, and control the functions of the human body. The use of hypnosis in analgesia according to Kihlstorm (1984) is more mediated by cognitive processes and not directly influenced by physiological processes. The success of hypnosis in analgesia or often referred to as hypnoanalgesia is not associated with an increase in serum beta endorphins (Spiegel and Albert, 1983 in Kihlstorm, 1984). Hypnoanalgesia is thought to block the entry of consciousness by activating the frontal limbic system to inhibit the transmission of pain impulses from the thalamus to the cortical structures. Another theory suggests that hypnoanalgesia can relieve pain by decreasing activity in the anterior cingulated cortex rather than affecting the activity of the cortex. Implanted suggestions are able to make the patient experience deep relaxation, change the character of pain and change a person's attitude towards pain shows positive results.
According to Prasetya et al. (2018) and Iserson (2014) under the influence of hypnosis, the cerebral cortex experiences strong inhibition, so that the power of identification, analysis, decision making of new stimuli decreases, past experiences cannot be utilized, as a result suggestive words become strength irresistible dominant. In the hypnosis condition, through active direction, the patient's condition and behavior, both psychological and physiological, can be controlled, so that it can eliminate or heal the psychological or physiological obstacles experienced by the patient. However, the patient's response is also strengthened by the ability of the hypnotist / therapist's approach.

\section{AUTHOR CONTRIBUTION}

Hanung Prasetya is the main writer who writes manuscripts, processes data and compiles hypnotherapy audio instruments. Heni Nur Kusumawati and Wardiyatmi formulated study methods and collected research and discussion materials.

\section{CONFLICT OF INTEREST}

There is no conflict of interest in this study.

\section{FUNDING AND SPONSORSHIP}

This research was funded by the Research for Health Personnel Development of the Ministry of Health of the Republic of Indonesia.

\section{ACKNOWLEDGEMENT}

Acknowledgments were conveyed by the authors to the director of the Dr. Moewardi Hospital for allowing this study to be carried out. Thank you to all the health personnel for helping in data collection. Thank you to all patient with cancer cervics who have been willing and cooperative to become the study subjects. 


\section{REFERENCE}

Arter D (2014). Step by step of learning the power of Hypnosis. Yogyakarta: Arasaka.

Benson H, Proctor (2000). Relaxation response basics. Edisi 1 Bandung Kaifa.

Brooker C (2009). Ensiklopedia Keperawatan. Jakarta: EGC.

Eisenberg E, Borsook D, LeBes AA (1996). Pain in terminally ill. The Masachusetts General Hospital Handbook of Pain Management. 1st ed. Little Brown.

Green JP, Barabasz AF, Barret D, Montgomery GH (2005). Forging a head: The 2003 APA Definition of Hypnosis. Int J Clin Exp Hypn. 53(3): 259-64. https://doi.org/10.1080/0020714059 0961321.

Guardian L, Harjanto E (2007). Tata laksana farmakologis nyeri kanker (Pharmacological Management of Cancer Pain). Journal of Cancer. 3, 121-123. https://media.neliti.com/media/publi cations/70035-ID-tata-laksana-farmakologis-nyeri-kanker.pdf.

Gunawan, Adi W (2006). Hypnotherapy: The art of subsconcious restructuring. Jakarta: Gramedia Pustaka Utama.

Hermes D, Truebger D, Hakim SG, Sieg P (2005). Tape recorded hypnosis in oral and maxillofacial surgery-basics and first clinical experience. J Craniomaxillofac Surg. 33(2): 123-9. https://doi.org/10.1016/j.jcms.2004.06.00 9.

Iserson, Kenneth V (2014). An hypnotic suggestion: Review of hypnosis for clinical emergency care. The Journal of Emergency Medicine J Emerg Med. 46(4): 588-96. https://doi.org/10.1016/j.jemermed.2013.09.024.

Kemenkes RI (2015). National program guide for cancer prevention and early detection movement: Cervical cancer and breast cancer. Jakarta.

Kemenkes RI (2015). Panduan nasional penanganan kanker (National guide to cancer management), Kanker Serviks. Komite Nasional Penanggulangan Kanker (KPKN). Jakarta.

Kirsch I (1985). Response expectancy as a determinant of experience and behavior. American Psychologist 40 (11): 1189-1202. https://psycnet.apa.org/doi/10.1037/0003-066X.40.11.1189.

Lankton, Stephen. 2015. A SoC Model of Hypnosis and Induction. Am J Clin Hypn. 57(4): 367-377. https://doi.org/10.1080/00029157.2015.1011461.

Lubis RC (2018). Risk factors which influence the incidence of cervical cancer in women at RSUD Dr. Pirngadi, Medan. Theses. The University Institutional Repository: Universitas Sumatera Utara.

Murti B (2013). Desain dan ukuran sampel untuk penelitian kuantitatif dan kualitatif di bidang kesehatan (Design and sample size for quantitative and qualitative research in the health). Yogyakarta: Gadjah Mada University Press.

Sulistiya DP, Pramono D, Nurdiati D (2017). Faktor-faktor yang berhubungan dengan kejadian kanker serviks di rumah sakit Sardjito Yogyakarta (Related factors for cervical cancer incidence at Dr. Sardjito Hospital Yogyakarta). Berita Kedokteran Masyarakat. 33(3): 125-130. https://doi.org/10.22146/bkm.1716o.

Patterson DR, Tininenko, Schmidt AE, Sharar S (2004). Virtual reality hypnosis: A case report. Int J Clin Exp Hypn. 52(1): 27-38. https://doi.org/10.1076/iceh.52.1.27.23925. 
Prasetya et al./ The Effectiveness of Hypnotherapy in Reducing Pain

Parris WCV (1997). Cancer pain management: Principles and practice. 1st ed. Butterworth-Heinemann.

Hanung P (2017). Hanung induksi sebagai induksi hipnosis yang efektif, nyaman dan aman (Hanung induction as an effective, comfortable and safe hypnosis induction). Surakarta: Program Studi Ilmu Kesehatan Masyarakat Pascasarjana, Universitas Sebelas Maret.

Hanung P, Murti B, Anantanyu S Syamsulhadi M (2018). The effect of hypnosis on adherence to antituberculosis drugs using the health belief model. Int J Clin Exp Hypn. 66(2): 211-227. https://doi.org/10.1080/00207144.2 018.1421361.

Potter, Perry (2005). Buku ajar fundamental keperawatan. Jakarta: EGC.

Rasjidi I (2010). Perawatan Paliatif Suportif \& Bebas Nyeri Pada Kanker. Jakarta: Sagung Seto.

Rogovik AL, Goldman RD (2007). Hypnosis for treatment of pain in children. Canadian Family Physician Journal. 53(5): 823-5. https://www.ncbi.nlm.nih.gov/pubmed/17872743.

Schnur JB, David D, Kangas M, Green S, Bovbjerg DH, Montgomery GH (2009). A randomized trial of cognitive-behavioral therapy and hypnosis intervention on positive and negative affect during breast cancer radiotherapy. J Clin Psychol. 65 (4): 443-
455. https://doi.org/10.1002/jclp.20559.

Shahbazi K, Solati K, Hasanpour-Dehkordi A (2016). Comparison of hypnotherapy and standard medical treatment alone on quality of life in patients with irritable bowel syndrome: A randomized controlled trial. J Clin Diagn Res. (5): OCo1-4. https://doi.org/10.$7860 / \mathrm{jcdr} / 2016 / 17631.7713$.

Suwiyoga IK (2007). Tes Human Papillomavirus sebagai Skrining Alternatif Kanker Serviks. http://www.kalbe.co.id/files/cdk/files/12_151_TestHuma nPapillomavirus.pdf/12_151_Test HumanPapillomavirus.html.

Smeltzer CS (2010). Medical surgical nursing. Lippincott Williams \& Wilkins: China.

Tamsuri A (2007). Konsep dan penatalaksanaannyeri . Jakarta : EGC.

Tarwoto, Wartonah (2010). Kebutuhan dasar manusia dan proses keperawatan. Edisi 4. Surakarta: PT Salemba Medika.

Wargo BW, Burton AW (2005). Cancer Pain, Pain Medicine and Managemen, Just The Fact. 1st ed. Mc Graw-Hill.

Woody EZ, Barnier AJ, McConkey KM (2005). Multiple hypnotizabilities: Differentiating the building blocks of hypnotic response. Journal Abnormal Psychology. 17(2): 200-211. https://doi.org/10.1037/1040-3590.17.2.200. 